\title{
Nitrogen and phosphorus availability at early stages of soil development in the Damma glacier forefield, Switzerland; implications for establishment of $\mathbf{N}_{2}$-fixing plants
}

\author{
Hans Göransson • Monika Welc • Else K. Bünemann • \\ Iso Christl • Harry Olde Venterink
}

Received: 17 August 2015 / Accepted: 29 January 2016/Published online: 1 March 2016

(C) The Author(s) 2016. This article is published with open access at Springerlink.com

\begin{abstract}
Background and aims Di-nitrogen $\left(\mathrm{N}_{2}\right)$-fixing plants are absent in the pioneer stages of glacial forefields in the European Alps despite low amounts of nitrogen $(\mathrm{N})$ in the soil. We aimed to evaluate whether symbiotic $\mathrm{N}_{2-}$ fixation is needed to meet the $\mathrm{N}$ demand of plants during the early stages of soil formation, and how phosphorus (P) availability affects plant establishment.

Methods We measured total and available $\mathrm{N}$ and $\mathrm{P}$ in soil and $\mathrm{N}$ and $\mathrm{P}$ in the vegetation along the 137 year chronosequence in front of the Damma glacier (Switzerland).
\end{abstract}

Responsible Editor: Benjamin L. Turner.

H. Göransson · H. O. Venterink

Institute of Integrative Biology, ETH Zurich, Universitätstrasse 16, CHN 8092 Zurich, Switzerland

M. Welc • E. K. Bünemann

Institute of Agricultural Sciences, ETH Zurich, Eschikon, 33, 8315 Lindau, Switzerland

I. Christl

Institute of Biogeochemistry and Pollutant Dynamics, ETH

Zurich, Universitätstrasse 16, 8092 Zurich, Switzerland

Present Address:

H. Göransson $(\bowtie)$

Institute of Forest Ecology, University of Natural Resources

and Life Sciences (BOKU), Peter-Jordanstrasse 82,

1190 Vienna, Austria

e-mail: hans.goeransson@boku.ac.at
Results Available $\mathrm{N}$ as determined by in situ resin $\mathrm{N}$ decreased from the pioneer stage $(<16$ years since deglaciation) to the intermediate (5780 years), likely resulting from increased plant $\mathrm{N}$ uptake and reduced funnelling of $\mathrm{N}$ by rocks. $\mathrm{N}$ concentrations in the vegetation were positively correlated to in situ resin $\mathrm{N}$, and the N:P-ratio of the vegetation was negatively correlated with $\mathrm{P}$ concentrations in the vegetation.

Conclusions The $\mathrm{N}$ requirement of plants in the pioneer stage of soil development in the forefield is fulfilled by atmospheric $\mathrm{N}$ deposition being funnelled between

Present Address:

M. Welc

Department of Crop Production Ecology, Swedish University

of Agricultural Sciences, Ulls väg 16, Box 7043, 750

07 Uppsala, Sweden

Present Address:

H. O. Venterink

Department of Biology, Vrije Universiteit Brussel, Pleinlaan

2, 1050 Brussels, Belgium
Present Address:

E. K. Bünemann

Research Institute of Organic Farmin, Ackerstrasse 113,

5070 Frick, Switzerland 
rocks. $\mathrm{N}_{2}$-fixation is not needed as the vegetation is often limited by $\mathrm{P}$, or co-limited by $\mathrm{N}$ and $\mathrm{P}$.

Keywords Alpine vegetation - Lotus alpinus . $\mathrm{N}_{2}$-fixation $\cdot$ Nitrogen $\cdot \mathrm{N}$ deposition $\cdot$ Phosphorus . Resin bags

\section{Introduction}

Glaciers in the European Alps have been withdrawing since the Little ice age ended in 1850 , creating chronosequences that can be used to study soil formation and vegetation succession (Matthews 1992). Just after a glacier has withdrawn, the rocky 'soil' lacks practically any organic material, and therefore nitrogen $(\mathrm{N})$, whereas phosphorus (P) is present mainly as apatite (Matthews 1992). Total $\mathrm{N}$ in the soil usually increases exponentially during the first 100 years after deglaciation, after which it reaches a plateau (Chapin et al. 1994; Jacobson and Birks 1980; Matthews 1992; Walker 1993). In contrast, total P usually declines with soil development as a result of weathering processes (Menge et al. 2012; Walker and Syers 1976). This increase in $\mathrm{N}$ and decrease in $\mathrm{P}$ means that the factor limiting plant growth may shift after several hundred to many thousands of years from $\mathrm{N}$ to $\mathrm{P}$ (Chapin et al. 1994; Wardle et al. 2004).

Some studies have shown that over the first 100 years after deglaciation $\mathrm{N}$ available to plants increases (Chapin et al. 1994), but other studies have found a decrease, or no pattern at all (Fitter and Parsons 1986; Jacobson and Birks 1980; Kohls et al. 2003). Similarly, plant available P has been reported to increase, decrease, or remain constant over the first 100 years of soil development (Darmody et al. 2005; Matthews 1992). Some of these differences between studies can be attributed to differences in climate, parent material, or to the methods used such as fertilization experiments and plant tissue nutrient concentration. Furthermore, to our knowledge, studies tracking changes in $\mathrm{N}$ and $\mathrm{P}$ availability during the growing season are still limited. (Chapin et al. 1994; Darmody et al. 2005; Fitter and Parsons 1986; Jacobson and Birks 1980; Kohls et al. 2003; Matthews 1992). Measuring these variations is important as nutrient availability and competition for nutrients change during the season as shown for alpine meadows (Jaeger et al. 1999).

The build-up of total $\mathrm{N}$ during soil development has often been ascribed to $\mathrm{N}$ input from symbiotic and asymbiotic $\mathrm{N}_{2}$ - fixation (Chapin et al. 1994; Luken and Fonda 1983; Matthews 1992). $\mathrm{N}_{2}$-fixing plants (symbionts) were consistently found to be dominant at recently deglaciated sites in some well-studied glacier forefields, such as Glacier Bay, Alaska (Chapin et al. 1994), Franz Joseph Glacier, New Zealand (Menge and Hedin 2009), and Santa Ines Island, Magellan Straits (Pérez et al. 2014). However, this appears not to be the case for the European Alps, where $\mathrm{N}_{2}$-fixing plants are usually absent from plant communities that are established during the first 30 years after deglaciation, and become significant parts of the vegetation only during later successional stages (Caccianiga and Andreis 2004; Cannone et al. 2008; Ellenberg 1996; Matthews 1992). Göransson et al. (2014) suggested that this might be due to the deposition of $\mathrm{N}$, which is funnelled into N-hotspots thereby removing the $\mathrm{N}$ limitation favouring non- $\mathrm{N}_{2}$-fixing plants. This raises the question of how $\mathrm{N}$ and $\mathrm{P}$ availability changes during primary succession in the European Alps, and whether $\mathrm{N}_{2}$-fixation is needed to fulfill the $\mathrm{N}$ requirement of plants during these young successional stages.

The overall aim of this study was to examine how the availability of $\mathrm{N}$ and $\mathrm{P}$ changes during early stages of soil development (7-137 years) at the Damma glacier forefield, Switzerland, and to relate this information to the nutritional status of the vegetation, and to the biomass of $\mathrm{N}_{2}$-fixing plants. Moreover, we aimed at evaluating whether symbiotic $\mathrm{N}_{2}$-fixation is required to meet the $\mathrm{N}$ demand of the vegetation along this gradient of soil development.

We measured total soil $\mathrm{N}$ and $\mathrm{P}$ pools as well as $\mathrm{N}$ and $\mathrm{P}$ adsorption rates to ion-exchange resin placed in situ, at 18 sites along a chronosequence during one growing season. These variables were linked to plant species composition, above ground biomass, and $\mathrm{N}$ and $\mathrm{P}$ concentrations of the vegetation. We expected that total $\mathrm{N}$ in soil, and $\mathrm{N}$ adsorption, to resin would increase with time since deglaciation, but that the successional time would be too short to find any changes in total P, or $\mathrm{P}$ adsorption to resin. Furthermore, we hypothesized that the abundance of $\mathrm{N}_{2}$-fixing plants would be negatively related to soil $\mathrm{N}$ availability.

\section{Methods}

Site description

The Damma glacier in the Swiss Alps has retreated by approximately $1000 \mathrm{~m}$ since the end of the Little ice age 
in 1850 (Gletscherberichte 1881-2002) (Fig. 1). During this period the glacier re-advanced twice: once between 1911 and 1928, and once from 1972 to 1991. The location of the glacier front has been recorded yearly since 1911 and earlier movements could be extrapolated (Gletscherberichte 1881-2002). Due to these movements, the forefield can be divided into three successional stages that were deglaciated at different times: (1) less than 16 years after deglaciation, (2) 57-80 years after deglaciation, and (3) more than 108 years after deglaciation.

The study was carried out at 21 sites on the chronosequence, ranging from 7 to 137 years after deglaciation. These sites of $4 \mathrm{~m}^{2}$ were randomly selected in May 2007 from within each of the three stages of forefield development for the 'BigLink' project (Bernasconi et al. 2011) (Fig. 1). The altitude of the experimental site is $2054 \mathrm{~m}$ at the front of the glacier,
Fig. 1 Location and areal photograph (Cnes/Spot image, Google, 2011) of the Damma forefield with sampling sites indicated (after Bernasconi et al. 2011). Stippled lines are side- and end-moraines

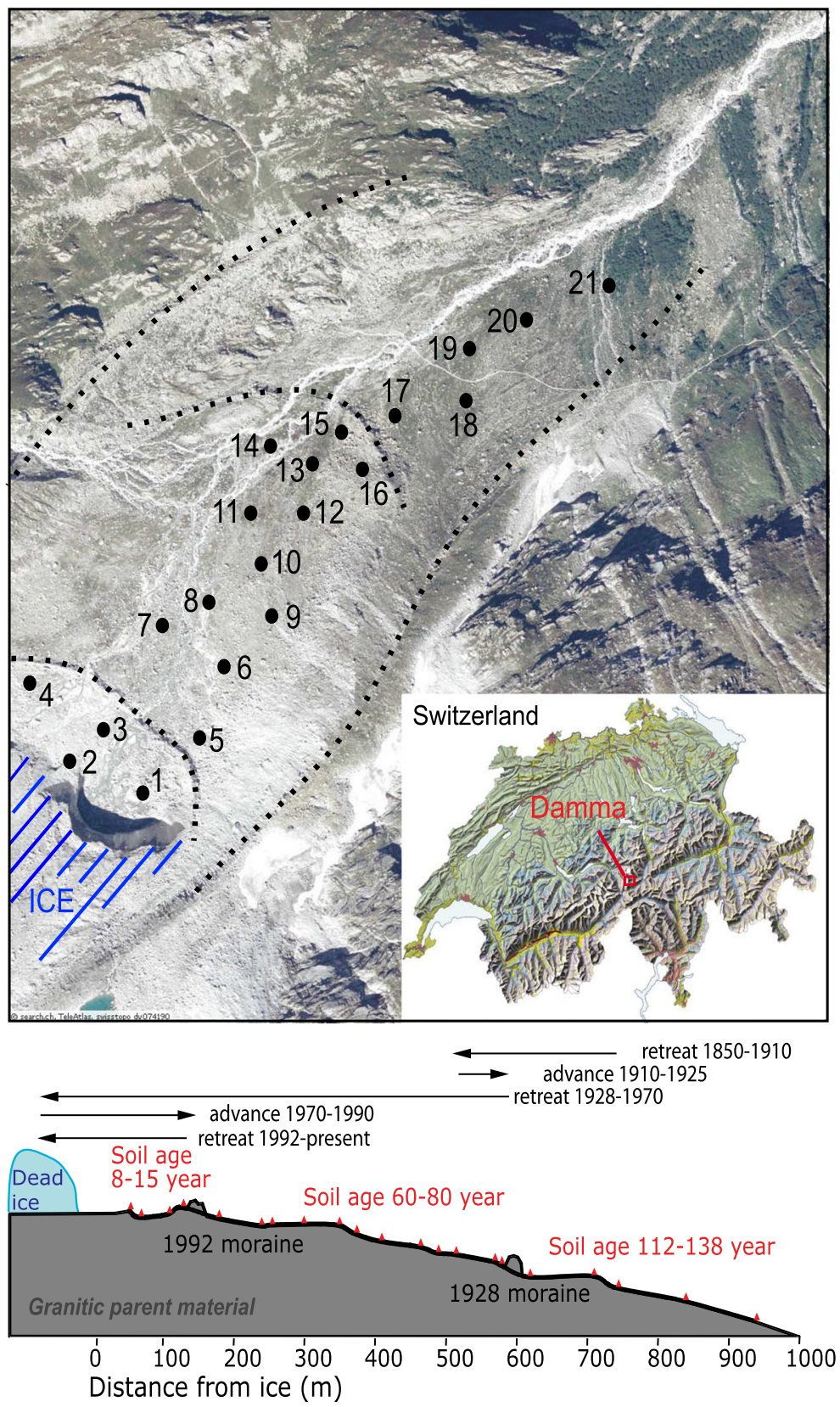


and $1920 \mathrm{~m}$ at $1 \mathrm{~km}$ from the ice, where the last sampling site is located. The bedrock in this area is Central Aar granite (Schaltegger 1990). Soils were classified as Hyperskeletic Leptosols, ranging from Eutric close to the glacier front to Dystric at a location deglaciated approximately 150 years ago (WRB 2006). From October 2007 to October 2009, the mean annual temperature measured on the forefield was $2.2^{\circ} \mathrm{C}$ and mean annual precipitation was $2300 \mathrm{~mm}$ yr (Kormann 2009).

\section{Vegetation and rocks}

Common plant species of the pioneer stage were Agrostis gigantea, Rumex scutatus and Cerastium uniflorum. The vegetation in the intermediate stage was dominated by Agrostis gigantea, Salix sp. and Deschampsia cespitosa. At the oldest stage, Rhododendron ferrugineum, Agrostis gigantea and Festuca rubra were the dominant plant species. The oldest site (site 21) of the gradient was dominated by Alnus viridis $\left(\mathrm{N}_{2}\right.$-fixing tree).

In July 2008, samples of the aboveground vegetation were taken by clipping all plants at $2 \mathrm{~cm}$ above the soil surface from three $0.2 \times 0.2 \mathrm{~m}$ squares at each site. If there was woody vegetation on the plot one square was also taken there. The samples were divided into woody plants, with leaves separated from the rest, and non-woody vegetation and dried at $40{ }^{\circ} \mathrm{C}$ for 5 days. After grinding and Kjeldahl digestion, tissue $\mathrm{N}$ and $\mathrm{P}$ concentrations in non-woody vegetation was determined by flowinjection spectrometry (FIAStar, Foss Tecator, Höganäs, Sweden). For each site, the proportion of area covered by vegetation and rocks was determined by analysing aerial photographs. These photographs were taken in 2008 from $4 \mathrm{~m}$ above the centre of the site, using a digital camera (Nikon D70, $18-70 \mathrm{~mm}$ ) mounted on a pole covering an area of $25 \mathrm{~m}^{2}$. Classification of vegetation and rocks was based on colour separation using Adobe Photoshop CS3 software (version 10.0.1, extended for Mac) (Smittenberg et al. 2012). To estimate annual foliar biomass production, the aboveground biomasses of non-woody plants, and the foliage biomass of woody plants (Salix sp., Rhododendron ferrugineum, and Alnus viridis) were summed. These values were extrapolated to the area of each experimental site using the coverage of bare soil, rocks, and vegetation (non-woody and woody plants) from aerial photographs taken at each site.

The aboveground biomass of Lotus alpinus was separately quantified in 2009 at all sites along the soil developmental gradient. Apart from Alnus viridis trees that were found at the at the oldest site, Lotus alpinus was the only $\mathrm{N}_{2}$-fixing species in the Damma glacier forefield, and hence its biomass represents that of the functional group ' $\mathrm{N}_{2}$-fixing plants' for the first 20 sites. At every site a $80 \mathrm{~m}$ transect parallel to the glacier front was established. All aboveground biomass of Lotus alpinus was harvested in five subplots along the transects. The sizes of these subplots were $4 \mathrm{~m}^{2}$ closest to the glacier (site 1-9 being younger than 67 years), and $1 \mathrm{~m}^{2}$ for the other sites. We used larger areas at the youngest sites to account for the greater heterogeneity of the vegetation.

\section{Soil $\mathrm{N}$ and $\mathrm{P}$ fractions}

Samples of the top soil $(0-5 \mathrm{~cm})$ were collected in September 2007 from each experimental site. The soil was sieved through a $2 \mathrm{~mm}$ sieve, air-dried, and ground to a fine powder (vibratory disc mill, Retsch), before analysis for $\mathrm{N}$ and $\mathrm{P}$.

Total N was measured by dry combustion (CHNS932, Leco). For total P measurement, $300 \mathrm{mg}$ of ground soil (Retsch mixer mill $200 \mathrm{M}, 30 \mathrm{~Hz}, 4 \mathrm{~min}$ ) were incinerated at $550{ }^{\circ} \mathrm{C}$ for $16 \mathrm{~h}$. The ashed samples were then digested with $1 \mathrm{ml} 65 \% \mathrm{HNO}_{3}$ at $250{ }^{\circ} \mathrm{C}$ for $2 \mathrm{~min}$. Each digested sample was transferred into a volumetric flask, diluted to $25 \mathrm{ml}$ with distilled water and homogenized by mixing (Welc et al. 2014). Extracts were filtered through $0.20 \mu \mathrm{m}$ filters (Santorius), and total $\mathrm{P}$ was measured colorimetrically at $\lambda=610 \mathrm{~nm}$ (UV 1601 Spectrophotometer, Shimadzu) using malachite green (Fluka AG, Switzerland) as a colour agent (Ohno and Zibilske 1991).

\section{In situ resin $\mathrm{N}$ and $\mathrm{P}$}

In June 2008 five bags containing ion-exchange resin were buried at $2.5 \mathrm{~cm}$ depth at the 18 sites that were not still covered by avalanche snow (Site: 1, 5 and 6). Before use, the resin in the bags $(4 \times 4 \mathrm{~cm}$ nylon mesh bags, $50 \mu \mathrm{m}$, with $2 \mathrm{~g}$ mixed resin Amberlite IRN150, Sigma Aldrich, Switzerland) was preconditioned by shaking vigorously in $2 \mathrm{M} \mathrm{KCl}$ for $2 \mathrm{~h}$ and then slowly rinsed in deionised water for 2 days. These bags were 
collected from the field in September 2008, after 110 days of incubation in the soil. In addition, five bags were buried at site 2 and 4 in the pioneer stage $(<$ less than 16 years after deglaciation), site 9 and 12 in the intermediate stage (between 57 and 80 years after deglaciation) and site 17 and 19 in the old stage (108137 years after deglaciation). After 37 days (in July 2008) these bags were collected and new bags were inserted at the same place. These bags which were replaced again after a further 36 days (in August 2008) and the last set of bags were collected after another 37 days together with the bags that had been in the soil all summer. The collected bags were kept frozen until extraction. To extract $\mathrm{N}$ and $\mathrm{P}$, the bags were quickly rinsed in deionized water to remove adhering soil particles, and then shaken in $50 \mathrm{~mL} 1 \mathrm{M} \mathrm{KCl}$ for $2 \mathrm{~h}$ at room temperature. The bags were removed and the obtained solutions were kept frozen until analysis of $\mathrm{NH}_{4}{ }^{+}, \mathrm{NO}_{3}{ }^{-}$, and $\mathrm{PO}_{4}{ }^{3-}$ by flow injection spectrometry (FIAStar, Foss Tecator, Höganäs, Sweden). Because the sum of ammonium-N and nitrate-N highly correlates with $\mathrm{N}$ mineralization it was used as a measure of $\mathrm{N}$ availability (Binkley et al. 1986; Giblin et al. 1994). In situ resin N:P ratio was calculated from the means of in situ resin $\mathrm{N}$ and $\mathrm{P}$ of each experimental site. To avoid nonsensical $\mathrm{N}: \mathrm{P}$ ratios at the sites where no $\mathrm{P}$ could be detected (sites $8,16,20$ and 21), the adsorbed $P$ was set to the detection limit.

\section{Statistics}

Changes in total and extractable soil pools of $\mathrm{N}$ and $\mathrm{P}$ as well as vegetation biomass and cover along the soil development gradient (time since deglaciation) were analysed by means of regression. We also calculated linear regressions, i.e., vegetation $\mathrm{N}$ and $\mathrm{P}$ concentrations vs. resin $\mathrm{N}$ and resin $\mathrm{P}$ (incubated for 110 days), and vegetation $\mathrm{N}: \mathrm{P}$ ratio $v s$. vegetation $\mathrm{N}$ and $\mathrm{P}$ concentrations. Differences in resin $\mathrm{N}$ and resin $\mathrm{P}$ among the three stages of the forefield were analysed by means of one-way ANOVA using the mean value of a given parameter for each site and time point. Variancestabilizing LN transformation of the data were applied when needed. The $\mathrm{N}$ deposition funnelled into the space in between the rocks was calculated as the N-deposition $\left(\mathrm{kg} \mathrm{ha}^{-1} \mathrm{y}^{-1}\right) \times(100 / \%$ area not covered by rocks $)$. Calculations assumed an overall $\mathrm{N}$-deposition rate of $10 \mathrm{~kg} \mathrm{ha}^{-1} \mathrm{y}^{-1}$. All analyses were done with SPSS 21 for Mac (IBM, New York).

\section{Results}

Total and available $\mathrm{N}$ and $\mathrm{P}$ in soil

Total $\mathrm{N}$ in soil increased exponentially along the soil developmental gradient. (Fig. 2a). The in situ resin N from bags incubated in the soil for 110 days was high in pioneer stage sites, and tended to decline $(p=0.06)$ towards the intermediate stage, and then increased again towards the end of the oldest stage of the developmental gradient (Fig. 2b). The in situ resin $\mathrm{N}$ measured from bags incubated for 36-37 days was significantly higher in the pioneer stage sites than in the intermediate, and also in the old stages in June-July and July-August (Fig. 3). In August-September, a similar but statistically insignificant trend was observed among the three developmental stages of the forefield. Neither total $\mathrm{P}$ (Fig. 2c), nor in situ resin P (110 days) (Fig. 2d), varied significantly along the chronosequence, but available $\mathrm{P}$ concentrations were below the detection limit at the two oldest sites (Fig. 2d, short incubation data not shown). The resulting N:P ratios of the resin bags buried for 110 days showed a similar pattern to the resin bag $\mathrm{N}$, with the lowest $\mathrm{N}: \mathrm{P}$ ratio in the intermediate part of the forefield (Quadratic fit $p=0.009, R^{2}=0.490$ $\left.y=0.024 \mathrm{x}^{2}-2.596 \mathrm{x}+56.722\right)$ (Fig. 2e) .

Vegetation cover and plant nutrient concentrations

Vegetation cover increased linearly with soil development after deglaciation reaching almost $100 \%$ cover at the oldest sites (Fig. 4a) Aboveground biomass (excluding wood) increased exponentially along the successional gradient, with a tendency to level out in the oldest stage before site 21 (deglaciated 136 years ago), the site with Alnus viridis trees (Fig. 4b). The coverage by rocks decreased with soil age after deglaciation from over $90 \%$ to less than $10 \%$ (Fig. 4a). The N-deposition funnelled into the surface area between the stones, available for plant colonization, was much higher at the pioneer stage than at later stages (Fig. 5).

The leguminous species Lotus alpinus was absent in the pioneer stage sites, and its biomass tended to increase along the soil developmental gradient (Fig. 4c). The only other $\mathrm{N}_{2}$-fixing plant species, the tree Alnus viridis, occurred exclusively at the oldest site (site 21).

The concentration of $\mathrm{N}$ in the aboveground nonwoody biomass was positively correlated with in situ resin $\mathrm{N}$ (Fig. 6a), but there was no equivalent 


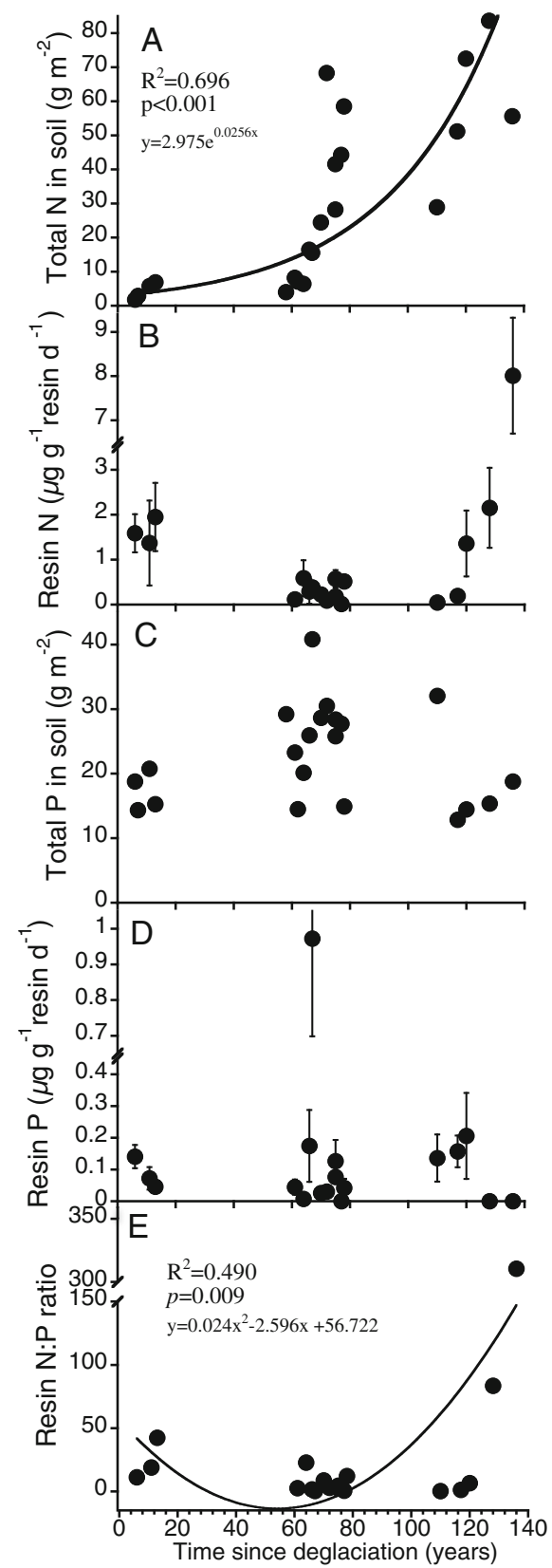

Fig. 2 Total and available $\mathrm{N}$ and $\mathrm{P}$ in the top $5 \mathrm{~cm}$ of the soil along a gradient of soil development at the Damma glacier forefield. (a) Total N in soil, (b) in situ resin adsorbed N, (c) Total P in soil, (d) in situ resin adsorbed $\mathrm{P},(\mathbf{e})$ and $\mathrm{N}: \mathrm{P}$ ratio of in situ resin. Resin bags were buried at $2.5 \mathrm{~cm}$ soil depth for 110 days from June to September 2008. Note that two y-axes $(\mathbf{b}, \mathbf{d})$ are broken. Error bars represent standard errors

relationship between $\mathrm{P}$ in the vegetation and in situ resin P (Fig. 6b). The N:P ratio of non-woody above-ground biomass varied between 8.5 and 23.5 (Fig. 7a). Differences in the N:P ratio of the vegetation were

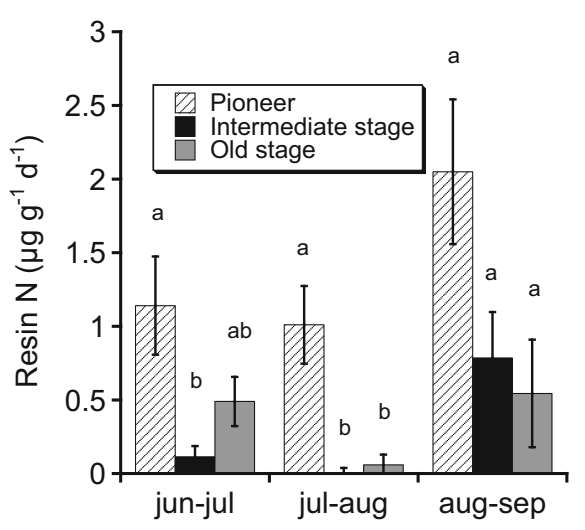

Fig. 3 Nitrogen adsorption to resin in bags buried at two sites per successional stage in the Damma glacier forefield, during three consecutive periods of 37 days each from June to September 2008. Pioneer Stage of soil development $<16$ years after deglaciation, Intermediate Stage 57-80 years, and Old Stage 108-136 years. Different letters indicate significant differences between the parts of the forefield . Values are the mean of two observation \pm standard error)

driven by $\mathrm{P}$, as the $\mathrm{N}: \mathrm{P}$ ratio was not correlated to the $\mathrm{N}$ concentration, but negatively correlated to the $\mathrm{P}$ concentration of the vegetation (Fig. $7 \mathrm{~b}$ and c).

\section{Discussion}

Nitrogen

Total $\mathrm{N}$ in the soil of the Damma glacier forefield increased exponentially during the first 137 years of soil development, as we expected based on data collected from other glacier forefields (Chapin et al. 1994; Jacobson and Birks 1980; Matthews 1992; Walker 1993). However, there were setbacks behind each end moraine, probably caused by disturbances such as burial of sites with new $\mathrm{C}$ and $\mathrm{N}$-free sediment, (partial) erosion, and reduction of standing biomass during the readvance of the glacier (Smittenberg et al. 2012) In situ resin $\mathrm{N}$ - which can be regarded as a measure of plant available $\mathrm{N}$ - showed a different pattern; it decreased from the pioneer stage of succession (first 16 years of soil development) to the intermediate stage of the successional gradient (60-80 years). The high availability of $\mathrm{N}$ in the pioneer stage implies that the input of $\mathrm{N}$ exceeds the uptake. Atmospheric deposition is the major input of $\mathrm{N}$ in this young soil, which is still low in organic matter due to poor development of the vegetation cover. The deposition was estimated to be approximately 5 to 


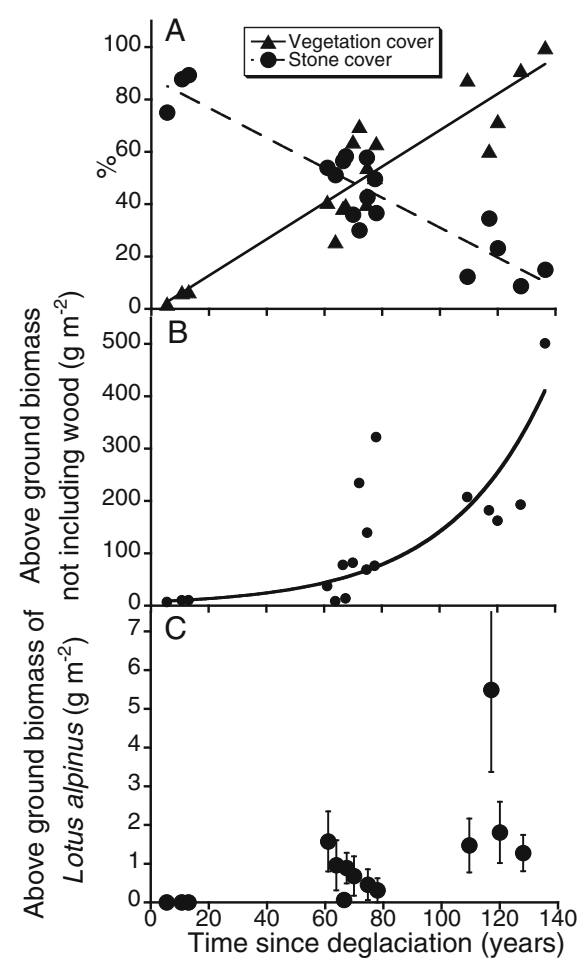

Fig. 4 Area covered by vegetation (solid line, $R^{2}=0.835$, $p<0.001)$ or rocks (dotted line, $\left.R^{2}=0.648 p<0.001\right)$ ) (a), total aboveground biomass (excluding wood) $\left(R^{2}=0.692, p<0.001\right)$ (b) and aboveground biomass of Lotus alpinus (c), along the gradient of soil development in the Damma glacier forefield

$10 \mathrm{~kg} \mathrm{ha}^{-1} \mathrm{y}^{-1}$ and was even higher in the 1980s (FOEN 2000; Graber et al. 1996; Göransson et al. 2014; Schöpp et al. 2003). Other $\mathrm{N}$ sources, such as $\mathrm{N}_{2}$-fixation by free-living microbes at Damma appeared to be negligible (Brankatschk et al. 2010; Noll and Wellinger 2008), and legumes or other symbiotic $\mathrm{N}_{2}$-fixing plants are absent at the pioneer stage.

Göransson et al. (2014) showed that at the pioneer stage of the Damma glacier forefield $\mathrm{N}$ in rain is funnelled by the rocks into the areas where plants grow, resulting in 10 times higher available $\mathrm{N}$ concentration near rocks compared to further away. The higher concentration of $\mathrm{N}$ in close vicinity of rocks was mirrored in the $\mathrm{N}$ concentration of plants, which was higher in plants growing next to the rocks compared to those growing further away. Due to the deposition of glacial sediments, and accumulation of plant-originated organic matter, rocks are buried in the soil as the time proceeds (Smittenberg et al. 2012) (Fig. 8). Therefore, the area of rocks above the surface decreased from almost $90 \%$ on the young sites to only $10 \%$ at the oldest (Fig. $4 a$ ). The high area coverage by rocks at the pioneer sites

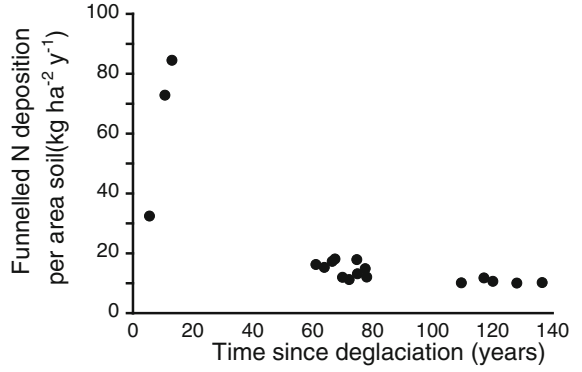

Fig. 5 Amount of $\mathrm{N}$ at the different sites that is deposited by funnelling of surrounding rocks into the area between the rocks where plants are able to grow. $\mathrm{N}$ deposited $=\mathrm{N}$-deposition $\left(\mathrm{kg} \mathrm{ha}^{-1}\right.$ $\left.\mathrm{y}^{-1}\right) \times(100 / \%$ area not covered by rocks $)$. Calculations assumed an overall $\mathrm{N}$-deposition rate of $10 \mathrm{~kg} \mathrm{ha}^{-1} \mathrm{y}^{-1}$

increases the $\mathrm{N}$ deposition into the areas where plants grow up to 8 times as compared to the old sites (Fig. 5). Hence, the high in situ resin $\mathrm{N}$ values at pioneer sites are due to funnelled rain, resulting in $\mathrm{N}$ levels that exceed the requirement for $\mathrm{N}$ of the plants sparsely colonizing these sites. Chapin (1993) suggested that favourable microsites are more common, and thus important for establishment at pioneer stages compared to later successional stages. Funnelling of rain can create such favourable microsites.

In situ resin $\mathrm{N}$ was particularly low in the intermediate part of the forefield in July-August (Fig. 3), which is the time period of most intensive plant growth. The decreased $\mathrm{N}$ availability in the middle of the studied chronosequence is partly due to increased abundance of plants, and partly due to the decreased cover of rocks and an associated reduction of funnelled $\mathrm{N}$ per unit area suited for plant growth.

At approximately 120 years after deglaciation, in situ resin $\mathrm{N}$ increased again (Fig. 2b). A higher availability of $\mathrm{N}$ after 120 years is likely to result from a combination of increased turnover of organic N (Tscherko et al. 2003) and a stabilization of vegetation biomass in the oldest part of the forefield. Consequently, during later successional stages $\mathrm{N}$ availability increases faster than $\mathrm{N}$ demand by the vegetation (Fig. 4b). At the oldest site (137 years since deglaciation) the high $\mathrm{N}$ availability is likely due to the presence of the $\mathrm{N}_{2}$-fixing shrub, Alnus viridis.

\section{Phosphorus}

Total $\mathrm{P}$ and in situ resin $\mathrm{P}$ didn't show significant patterns along the developmental gradient. According to the theory of soil development, total 

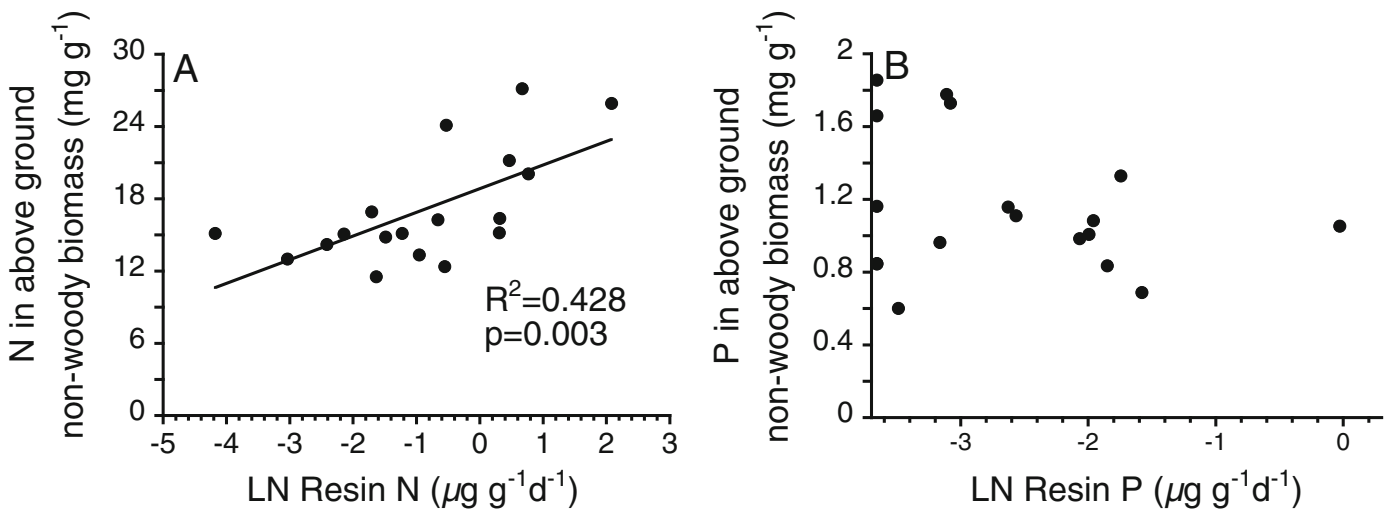

Fig. 6 Relationship between (a) N concentration and (b) P concentration in the aboveground non-woody biomass and $\mathrm{N}$ respectively $\mathrm{P}$ adsorbed to resins in situ buried for 110 days

soil $\mathrm{P}$ and available amounts of mineral $\mathrm{P}$ tend to decrease with time (Menge et al. 2012; Walker and Syers 1976; Wardle et al. 2004), but the Damma chronosequence is far too short to observe such decreases as the main P-containing mineral is slowly weathering fluorapatite (Bernasconi et al. 2011). The absence of differences in in situ resin $\mathrm{P}$ along the forefield, and of a correlation between resin $\mathrm{P}$ and the $\mathrm{P}$ concentration in the vegetation, can be due to excessive $\mathrm{P}$ uptake by the vegetation, keeping the available amount of $\mathrm{P}$ in the soil low. The small variation in in situ $\mathrm{P}$ along the chronosequence as compared to in situ $\mathrm{N}$ results in a decreasing in situ resin $\mathrm{N}: \mathrm{P}$ ratio from the pioneer to the intermediate stage, and increasing again in the older stage (Fig. 2e). This suggests that the $\mathrm{N}$ limitation of the vegetation is strongest in the intermediate part, and that the vegetation might be more limited by $\mathrm{P}$ than by $\mathrm{N}$ in the youngest and oldest stages of soil development.
Nutrient limitation of the vegetation

$\mathrm{N}: \mathrm{P}$ ratios $>19$ in the aboveground vegetation indicate that plant growth was not only limited by N, but either co-limited by $\mathrm{N}$ and $\mathrm{P}$ or limited by $\mathrm{P}$ alone, at several sites and at all three stages of the Damma forefield (Fig. 7a; Olde Venterink et al. 2003). Although plants might need relatively more $\mathrm{N}$ at high than at lower altitudes (Körner 1989), also N:P ratios $<19$ can indicate co-limitation by $\mathrm{N}$ and $\mathrm{P}$, as observed for another alpine vegetation (Bowman 1994). This suggests that the nutritional condition of the vegetation might fluctuate between $\mathrm{N}$ and $\mathrm{P}$ limitation, with several sites probably being co-limited. The negative correlation between the N:P ratio and the $\mathrm{P}$ concentration of the vegetation, and the lack of a similar correlation for $\mathrm{N}$ ( $6 \mathrm{~b}$ and $\mathrm{c}$ ), suggests that the availability of $\mathrm{P}$ is regulating the N:P ratio of the plants. Consequently, a high $\mathrm{N}: \mathrm{P}$ ratio is due to a low availability of $\mathrm{P}$ rather than a high availability of $\mathrm{N}$.

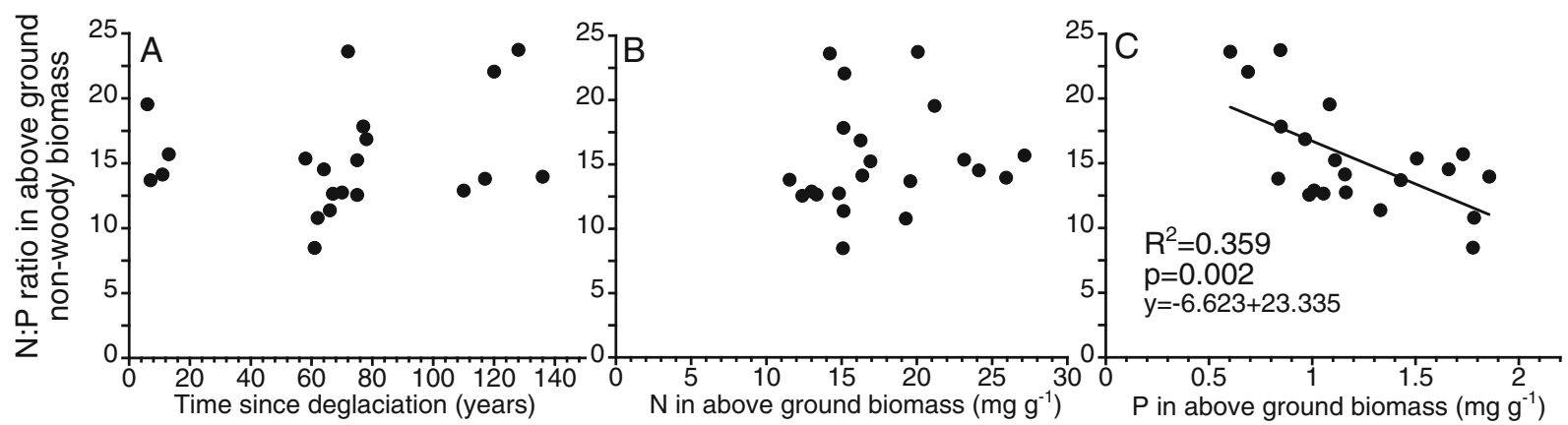

Fig. 7 (a) N:P ratio of the non-woody vegetation along the chronosequence, (b) N:P ratio versus N concentration of the non-woody vegetation, and (c) $\mathrm{N}: \mathrm{P}$ ratio versus $\mathrm{P}$ concentration of the non-woody vegetation 

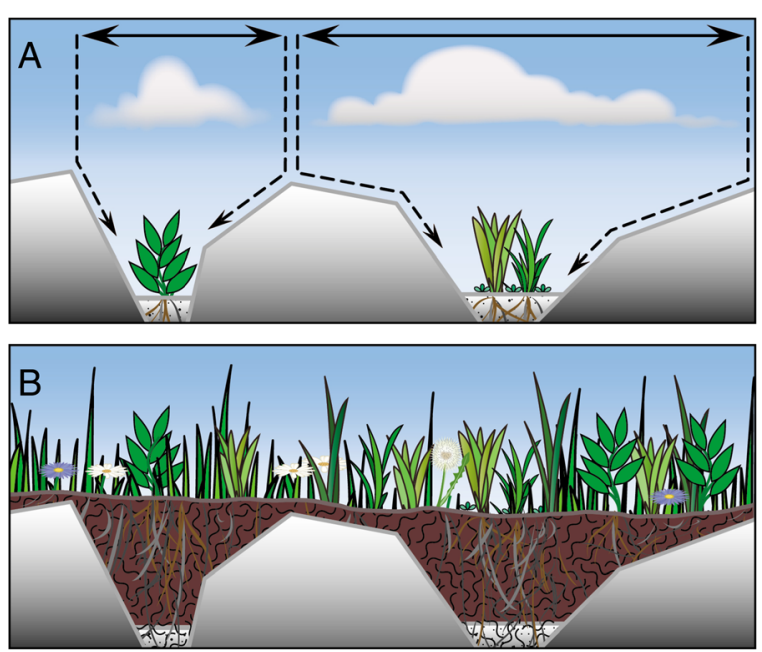

Fig. 8 Schematic illustration of the build-up of soil between bare rocks during early soil development. At the pioneer stage the surrounding rocks function as a funnel (dotted lines) for atmospheric $\mathrm{N}$ deposition, creating nutritional hotspots in the depressions between the rocks. During succession the soil level increases from the pioneer stage (a) to the old stages (b) due to accumulation of plant roots, organic matter and sediments

A similar pattern of N, P as well N-P co-limitation as indicated for plants was observed for bacteria of the Damma forefield. Göransson et al. (2011) found that bacterial growth in the Damma glacier forefield was generally more $\mathrm{N}$ than $\mathrm{P}$ limited, when C-limitation was removed, but that bacteria were more $\mathrm{P}$ than $\mathrm{N}$ limited at eight sites. These included two sites in the pioneer stage as well as the two oldest sites of the chronosequence where in situ resin-P was undetectable and in situ resin $\mathrm{N}$ was high.

\section{$\mathrm{N}_{2}$-fixing plants}

The changed balance between $\mathrm{N}$ demand and $\mathrm{N}$ availability from the pioneer to the intermediate stage might temporally turn the system more towards $\mathrm{N}$ limitation. This coincides with the establishment and growth of the $\mathrm{N}_{2}$-fixer Lotus alpinus, albeit in relatively modest proportions in the vegetation (cf. Fig. $4 b, c)$. In the pioneer stages symbiotic $\mathrm{N}_{2}$-fixing plants were absent, as is usual in the pioneer stages of glacial forefields in the Alps (Caccianiga and Andreis 2004; Cannone et al. 2008; Ellenberg 1996; Matthews 1992). In areas with low N-deposition like Puca Glacier in the Andes, Glacier Bay, Alaska and Franz Josef Glacier, New Zealand (approximately $1 \mathrm{~kg} \mathrm{~N} \mathrm{ha}{ }^{-1} \mathrm{y}^{-1}$ ), $\mathrm{N}_{2}$-fixation is abundant in the pioneer stages of succession (Chapin et al. 1994; Menge and Hedin 2009; Schmidt et al. 2008). The lack of $\mathrm{N}_{2}$-fixing plants at many places in the European Alps might be related to the high $\mathrm{N}$ deposition, but also to a low $\mathrm{P}$ availability. A low $\mathrm{P}$ availability decreases the competitive ability of the $\mathrm{N}_{2}$-fixing plants, but may also directly decrease root infection with symbiotic microbes (bacteria and actinomycetes), or impair functioning of the symbiotic consortia (Augusto et al. 2013). This may have been the case at the Athabasca Glacier, Canada where the normally $\mathrm{N}_{2}$-fixing plant Dryas drummondii did not form nodules during the first 50 years after deglaciation (Kohls et al. 1994). Based on the natural abundance of ${ }^{15} \mathrm{~N}$ in Lotus alpinus in comparison to that in the reference plants Leucanthemopsis alpina, Agrostis gigantea and Leontodon sp., Ami (2010) estimated that more than $80 \%$ of the $\mathrm{N}$ in Lotus alpinus at the Damma forefield could have been derived from $\mathrm{N}_{2}$-fixation in the Damma forefield. Nevertheless, due to the low biomass of this species on the forefield, the amount of fixed $\mathrm{N}_{2}$ was only maximum $0.06 \mathrm{~kg} \mathrm{ha}^{-1} \mathrm{y}^{-1}$ in the intermediate part of the forefield increasing up to $0.8 \mathrm{~kg} \mathrm{ha}^{-1} \mathrm{y}^{-1}$ in the oldest part. Thus, the contribution of Lotus alpinus to the $\mathrm{N}$ accumulation was only $8-16 \%$ of that of deposition-originated N (Ami 2010).

The high $\mathrm{N}$ availability in the pioneer stage that appears to create at least local P-limited conditions may affect the importance of functional aspects of plants. Species good at mobilizing mineral-P should have a competitive advantage in colonizing the sites. For example, Rumex scutatus, the second most common plant species, seems to be one of those species. At the Damma glacier forefield, Rumex scutatus was found to have higher amounts of organic acids in the rhizosphere than, for example, Agrostis gigantea (Görnasson, unpublished data). Göransson et al. (2014) found that Rumex scutatus had the same low $\mathrm{N}: \mathrm{P}$ ratio (c. 11) in the leaves independent of whether it grew next to a funnelling stone or not. In contrast, Agrostis gigantea had a significantly higher N:P ratio (24) when growing next to stones than when in open spaces $(N: P=18)$. Thus, plants mobilizing $\mathrm{P}$ from mineral-derived sources, such as apatite, might be more important than $\mathrm{N}_{2}$-fixing species as pioneer plants, at least in the areas with granite /silicate bedrock which is a common lithology in the European Alps (Blume et al. 2015). 


\section{Conclusions}

The results from this study suggest that, where the already high deposition rates are further enhanced by the funnelling of precipitation by rocks, $\mathrm{N}$ input from atmospheric deposition is the main source of $\mathrm{N}$ in primary succession in the European Alps (Göransson et al. 2014). In combination with the low weathering rate and slow release of $\mathrm{P}$ from minerals upon weathering, this leads to P- or N-P co-limitation of the vegetation during early stages of succession. This is in contradiction to studies done in areas with low $\mathrm{N}$-deposition. $\mathrm{N}_{2}$-fixation, which is considered in many textbooks as a main process contributing to accumulation of $\mathrm{N}$ in the system, plays only a minor role in primary succession in glacier forefields in the European Alps and seems to be less important for establishment and succession of the vegetation at the initial stage of its development. The importance of $\mathrm{N}$ deposition as $\mathrm{N}$ source at this young alpine sites implies that the critical $\mathrm{N}$ load from deposition for alpine habitats $\left(5-15 \mathrm{~kg} \mathrm{~N} \mathrm{ha}^{-1} \mathrm{y}^{-1}\right.$; Bobbink et al. 2010) may have to be lowered for these developmental stages (see Göransson et al. 2014).

Acknowledgments Open access funding provided by University of Natural Resources and Life Sciences (BOKU). The study was funded by the Competence Center Environment and Sustainability of the ETH Domain (CCES) through the BigLink project. We thank Kristel Perreijn for drawing Fig. 8 and Rienk Smittenberg for Fig. 1.

Open Access This article is distributed under the terms of the Creative Commons Attribution 4.0 International License (http:// creativecommons.org/licenses/by/4.0/), which permits unrestricted use, distribution, and reproduction in any medium, provided you give appropriate credit to the original author(s) and the source, provide a link to the Creative Commons license, and indicate if changes were made.

\section{References}

Ami H (2010) Symbiotic nitrogen fixation by Lotus alpinus along the chronosequence of the Damma glacier forefield. Bachelor thesis. Institute of Integrative Biology, ETH Zürich

Augusto L, Delerue F, Gallet-Budynek A, Achat DL (2013) Global assessment of limitation to symbiotic nitrogen fixation by phosphorus availability in terrestrial ecosystems using a meta-analysis approach. Glob Biogeochem Cycles 27:804815

Bernasconi SM, Bauder A, Bourdon B, Brunner I, Bünemann E, Chirs I, Derungs N, Edwards P, Farinotti D, Frey B, Frossard E, Furrer G, Gierga M, Göransson H, Gülland K, Hagedorn F, Hajdas I, Hindshaw R, Ivy-Ochs S, Jansa J, Jonas T,
Kicyka M, Kretzchmar R, Lemarchand E, Luster J, Magnusson J, Mitchell EAD, Olde Venterink H, Plötze M, Reynolds B, Smittenberg RH, Stähli M, Tamburini F, Tipper ET, Wacker L, Welc M, Wiederhold JG, Zeyer J, Zimmermann S, Zumsteg A (2011) Chemical and biological gradients along the Damma Glacier soil chronosequence (Switzerland). Vadose Zone J10:867-883

Binkley D, Aber J, Pastor J, Nadelhoffer K (1986) Nitrogen availability in some wisconsin forests: comparisons of resin bags and on-site incubations. Biol Fertil Soils 2:77-82

Blume H-P, Brümmer GW, Fleige H, Horn R, Kandeler E, KögelKnabner I, Kretzschmar R, Stahr K, Wilke B-M (2015) Scheffer/Schachtschabel soil science. Springer, Berlin Heidelberg

Bobbink R, Hicks K, Galloway J, Spranger T, Alkemade R, Ashmore M, Bustamante M, Cinderby S, Davidson E, Dentener F, Emmett B, Erisman J-W, Fenn M, Gilliam F, Nordin A, Pardo L, De Vries W (2010) Global assessment of nitrogen deposition effects on terrestrial plant diversity: a synthesis. Ecol Appl 20:30-59

Bowman WD (1994) Accumulation and use of nitrogen and phosphorus following fertilization in two alpine tundra communities. Oikos 261-270

Brankatschk R, Töwe S, Kleineidam K, Schloter M, Zeyer J (2010) Abundances and potential activities of nitrogen cycling microbial communities along a chronosequence of a glacier forefield. ISME 5:1025-1037

Caccianiga M, Andreis C (2004) Pioneer herbaceous vegetation on glacier forlands in the Italian Alps. Phytocoenologia 34: 55-89

Cannone N, Diolaiuti G, Gglielmin M, Smiraglia C (2008) Accelerating climate change impacts on alpine glacier forefield ecosystems in the european alps. Ecol Appl 18: 637-648

Chapin FS (1993) Physiological controls over plant establishment in primary succession. In: Miles J, Walton DWH (eds) Primary succession on land. Blackwell scientific publications, Oxford

Chapin FS, Walker LR, Fastie CL, Sharman LC (1994) Mechanisms of primary succession following deglaciation at glacier bay, Alaska. Ecol Monogr 64:149-175

Darmody RG, Allan CE, Thorn CE (2005) Soil Topochronosequences at Storbreen, Jotunheimen, Norway. Soil Sci Soc Am J 69:1275-1287

Ellenberg H (1996) Vegetation mitteleuropas mit den Alpen. Ulmer, Sturttgart

Fitter AH, Parsons WFJ (1986) Changes in Phosphorus and nitrogen availability on recessional moraines of the Athabasca Glacier, Alberta. Can J Bot 65:210-213

FOEN (2000) Nitrogen deposition 2000. The Swiss Federal Office for the Environment Bern

Giblin AE, Laundre JA, Nadelhoffer KJ, Shaver GR (1994) Measuring nutrient availability in artic soils using ion exchange resins: a field test. Soil Sci Soc Am J 58:115-1162

Gletscherberichte (1881-2002) Die Gletscher der Schweizer Alpen". Jahrbücher der Glaziologischen Kommission der Schweizerischen Akademie der Naturwissenschaften (SANW), herausgegegeben durch die Versuchsanstalt für Wasserbau, Hydrologie und Glaziologie (VAW). ETH, Zürich 
Göransson H, Olde Venterink H, Bååth E (2011) Soil bacterial growth and nutrient limitation along a chronosequence from a glacier forefield. Soil Biol Biochem 43:1333-1340

Göransson H, Edwards PJ, Perreijn K, Smittenberg RH, Venterink HO (2014) Rocks create nitrogen hotspots and N: P heterogeneity by funnelling rain. Biogeochemistry 121:329-338

Graber WK, Siegwolf RTW, Nater W, Leonardi S (1996) Mapping the impact of anthropogenic depositions on high elevated alpine forests. Environ Model Softw 11:59-64

Jacobson GL, Birks HJB (1980) Soil development on recent end moraines of the Klutan glacier, Yukon Territory, Canada. Quat Res (Orlando) 14:87-100

Jaeger CH, Monson KR, Fisk MC, Schmidt SK (1999) Seasonal partitoning of nitrogen by plants and soil microorganisms in alpine ecosystems. Ecology 80:1883-1891

Kohls SJ, van kessel C, Baker DD, Grigal DF (1994) Assessment of N2 fixation and N cycling by Dryas along a chronosequence within the forlands of the Athabasca glacier, Canada. Soil Biol Biochem 26:623-632

Kohls SJ, Baker DD, van kessel C, Dawson JO (2003) An assessment of soil enrichment by actinorhizal N2 fixation using $\partial 15 \mathrm{~N}$ values in a chronosequence of deglaciation at glacier bay, Alaska. Plant Soil 254:11-17

Kormann C (2009) Untersuchungen des Wasserhaushaltes und der Abflussdynamik eines Gletschervorfeldes. Master's thesis. TU Dresden

Körner C (1989) The nutritional status of plants from high altitudes. Oecologia 81:379-391

Luken JO, Fonda RW (1983) Nitrogen accumulation in a chronosequence of red alder communities along the Hoh River, Olympic National Park, Washington. Can J For Res 13:1228-1237

Matthews JA (1992) The ecology of recently deglaciated terrain: a geoecological approach to glacier forelands and primary succession. Cambridge University Press, Cambridge

Menge DN, Hedin LO (2009) Nitrogen fixation in different biogeochemical niches along a 120000 -year chronosequence in New Zealand. Ecology (NY) 90:2190-2201

Menge DN, Hedin LO, Pacala SW (2012) Nitrogen and phosphorus limitation over long-term ecosystem development in terrestrial ecosystems. PLoS One 7: DOI: 10.1371/journal.pone. 0042045

Noll M, Wellinger M (2008) Changes of the soil ecosystem along a receding glacier: testing the correlation between environmental factors and bacterial community structure. Soil Biol Biochem 40:2611-2619
Ohno T, Zibilske LM (1991) Determination of low concentrations of phosphorus in soil extracts using malachite green. Soil Sci Soc Am J 55:892-895

Olde Venterink H, Wassen MJ, Verkroost AWM, de Ruiter PC (2003) Species richness-productivity patterns differ between N, P and K limited wetlands. Ecology 84:2191-2199

Pérez CA, Aravena JC, Silva WA, Enríquez JM, Fariña JM, Armesto JJ (2014) Ecosystem development in short-term postglacial chronosequences: $\mathrm{N}$ and $\mathrm{P}$ limitation in glacier forelands from Santa Inés Island, Magellan Strait. Austral Ecol 39:288-303

Schaltegger U (1990) The Central Aar granite - Highly differentiated calc-alkaline magmatism in the Aar massif (Central Alps, Switzerland). Eur J Mineral 2:245-259

Schmidt SK, Reed SC, Nemergut DR, Grandy AS, Cleveland CC, Weintraub MN, Hill AW, Costello EK, Meyer AF, Neff JC, Martin AM (2008) The earliest stages of ecosystem succession in high-elevation (5000 meters above sea level), recently deglaciated soils. Proc R Soc Biol Sci Ser B 275:2793-2802

Schöpp W, Posch M, Mylona S, Johansson M (2003) Long-term development of acid deposition (1880-2030) in sensitive freshwater regions in Europe. Hydrol Earth Syst Sci 7:436446

Smittenberg RH, Gierga M, Göransson H, Christl I, Farinotti D, Bernasconi SM (2012) Climate-sensitive ecosystem carbon dynamics along the soil chronosequence of the Damma glacier forefield, Switzerland. Glob Chang Biol 18:1941-1955

Tscherko D, Rustemeier J, Richter A,WW, Kandeler E (2003) Functional diversity of the soil microflora in primary succession across two glacier foreland in the central alps. Eur J Soil Sci 54:685-696

Walker LR (1993) Nitrogen fixers and species replacement in primary succession. In: Miles J, Walton DWH (eds) Primary succession on land. Blackwell scientific publications, Oxford

Walker TW, Syers JK (1976) The fate of phosphorus during pedogenesis. Geoderma 15:1-19

Wardle DA, Walker LR, Bardgett RD (2004) Ecosystem properties and forest decline in contrasting long-term chronosequences. Science (Wash DC) 305:509-513

Welc M, Frossard E, Egli S, Bünemann EK, Jansa J (2014) Rhizosphere fungal assemblages and soil enzymatic activities in a 110-years alpine chronosequence. Soil Biol Biochem 74: 21-30

Wrb IWG (2006) World reference base for soil resources 2006. FAO, Rome 